\title{
Aviation Business Actor's Responsibilities for the Consumers
}

\author{
${ }^{1}$ Engeli Yuliana Lumaing* \\ Law Studies Program \\ Faculty of Social Science \\ Universitas Negeri Manado \\ Tondano, Indonesia \\ Engelilumaing.unima.ac.id
}

\author{
${ }^{2}$ Agustien Cherly Wereh \\ Law Studies Program \\ Faculty of Social Science \\ Universitas Negeri Manado \\ Tondano, Indonesia \\ cherlyagustienwereh@gmail.com
}

\begin{abstract}
This study aimed to determine explicitly legal protection for consumers in the form of accountability of commercial aviation business actors in Indonesia, to be able to produce a clear policy/regulation to protect consumers. The data sources come from secondary data which consists of primary, secondary and tertiary legal material. Primary legal material consists of the laws and regulations related to the UUPK, aviation Law and other relevant rules. Secondary legal material in the form of consumer protection books, papers, other scientific works related to consumer protection and even cases of aviation service consumers. The results of this study indicated the regulation of business actors' responsibilities both UUPK and UUP is unclear, as well as unprotected flight service consumers in Indonesia.
\end{abstract}

Keywords: Responsibility, Business Actors, Consumers

\section{INTRODUCTION}

Indonesia occupies the fourth position as the country with the largest population in the world, where China is the most populous country in the world, India, the United States and then Indonesia with a population of $242,775,796$ people [1]. Where around 74 million of them are middle-class consumers [2]. With a large population, it created a huge market opportunity for the aviation industry, especially Indonesia is an archipelagic country, consumers tend to have aviation services to conduct their activities outside the area/city. The number of consumers always increases every year in line with the increasing consumer demand for goods and services.

The aviation business is one of the fastest-growing businesses. This can be seen from the number of airplane transport passengers in recent years both domestically and abroad experiencing rapid growth, due to the geographical location of our country as an archipelago, the aviation sector is an important transportation tool for consumers.

The magnitude of consumer demand for air transport, to meet the needs of the consumer community for this aviation service, several companies engaged in the aviation industry are present in Indonesia, especially after the government privatized the aviation industry which was originally managed by SOEs, as regulated by Government Regulation No. 40 of 1999 then the
Department of Transportation gives the widest possible license to anyone who wants to get involved in the aviation industry, giving great opportunities to existing companies to conduct this field.

It cannot be denied, that the geographical location of Indonesia which is an archipelagic country, provides a great opportunity for the development of the aviation industry in Indonesia as a liaison between Indonesian regions. Until 2017 there were several companies engaged in the aviation industry present in Indonesia, with flight routes reaching almost the entire territory of the Republic of Indonesia. Some of them even serve overseas flight services. At present, there are several centuries of scheduled commercial air transport businesses operating. The list of scheduled commercial air transport business entities met the requirements are:

\begin{tabular}{|c|c|}
\hline No. & Airlines \\
\hline 1 & PT Garuda Indonesia \\
\hline 2 & PT Lion Mentari Airlines \\
\hline 3 & PT Indonesia Air Asia \\
\hline 4 & PT Trigana Air Service \\
\hline 5 & PT Sriwijaya Air \\
\hline 6 & PT Travel Express Aviation Service \\
\hline 7 & PT Wings Abadi \\
\hline 8 & PT Kalstar Aviations \\
\hline 9 & PT TRansnusa Aviation Mandiri \\
\hline 10 & PT Asi Pujiastuti Aviation \\
\hline 11 & PT Citilink Indonesia \\
\hline 12 & PT Batik Air \\
\hline 13 & PT Nam Air \\
\hline 14 & PT Indonesia Airasia Extra \\
\hline 15 & PT Tri MG Intra Asia Airlines \\
\hline 16 & PT Cardig Air (khusus cargo) \\
\hline 17 & PT My Indo Airlines (khusus cargo) \\
\hline
\end{tabular}

The presence of these airlines is certainly very helpful to the community, conducting their activities outside the region or region in the context of time efficiency, but the presence of airlines needs to be regulated, as not to harm consumers, because of several existing cases shows the number of consumers who have been disadvantaged due to flight delays or loss of luggage in the trunk, but in the end business actors often relinquish responsibility for consumer losses for a variety of reasons. Philosophically, this guarantee of legal certainty for consumers is implemented by referring to 
the 1945 Constitution of the Republic of Indonesia and Law No. 8 of 1999 concerning consumer protection as the principle and purpose of consumer protection.

Act No. 8 of 1999 regulates the responsibilities of business actors, as stated in article 19 of the UUPK, but this provision is not able to protect consumers of aviation services. The aviation sector is a rapidly growing business area, seen from the large number of airlines operating, but its presence needs to be regulated as not to harm consumers. The number of cases is often experienced by consumers, but they cannot claim their rights if harmed by consumers. For example, late hours of departure, passengers cannot fly while the status of the passenger on the ticket is registered as a passenger, loss of consumer luggage or even burglary of consumer luggage by unscrupulous airport officials.

Aviation operators should be fully responsible to consumers, but in fact, these responsibilities are not fulfilled, due to the lack of handling actions of the airlines because their existing insurance measures are not strict, which results in unprotected protection of airline customers. The government as a policy regulator in a country needs to pay serious attention to companies engaged in public service because it involves the interests of many people.

Article 3 Consumer protection aims to:

a. Increasing consumer awareness, ability, and independence to protect themselves.

b. Raise the dignity of consumers by avoiding the negative excess of using goods and / or services

c. Increasing the empowerment of consumers in choosing, determining and claiming their rights as consumers.

d. Creating a consumer protection system contains elements of legal certainty and information disclosure and access to information

e. Growing awareness of businesses about the importance of consumer protection honest and responsible attitudes grow in the business

f. Improving the quality of goods and / or services that ensure the continuity of the business of producing goods and /or services, health, comfort, security, and consumer safety.

\section{RESEARCH METHODS}

This research method is a normative juridical study using a statutory approach by examining all laws and regulations relating to the legal issues discussed.

\section{RESULT AND DISCUSSION}

In law, every demand for accountability should have a basis which is the thing causes a person to be (obliged) to be responsible. The basis of accountability according to civil law is the mistakes and risks that occurred in every legal event. Both lead to far different legal consequences and consequences in fulfilling the following responsibilities and matters relating to the prosecution procedure. [3]

Roscoe Pound in his book An introduction to the philosophy of law, states that responsibility comes or arises based on:[4] a. Agreement, where the parties who enter into the agreement are each required to be responsible for fulfilling or structuring the contents of the agreement that they have made themselves. b. Acts violating or against the law, which in reality can be divided into:

1. Self-action, whether intentional or unintentional

2. Actions of other people, but the person referred to here is a person who is still directly under the responsibility of the person in charge concerned. Example: loss / damage to other people's property due to a child's fault is the responsibility of the child's parent.

Events that do not constitute an act, but result in a consequence which must still be accounted for by the person who is considered the guarantor by law. Example: If a dog bites another person then the owner of the dog is responsible.

A concept related to the concept of legal liability is the concept of legal responsibility (liability). A person is said to be legally responsible for a particular act is that he can be subject to a sanction in the case of the opposite act. Normally, in the case of sanctions imposed on the delinquent it is because of his own actions that make the person responsible. In this case the subject of responsibility and the subject of legal obligation are the same. According to traditional theory, there are two types of accountability that are distinguished, namely accountability based on error and absolute responsibility [5], [6].

Absolute responsibility is a legal responsibility imposed on the perpetrator of an unlawful act regardless of whether the person involved in the act has an element of error or not, in this case the perpetrator can be held legally responsible, even though in doing the act he did not do it intentionally and nor does it contain any element of neglect, carelessness or non-compliance [7].

Therefore, absolute responsibility is often referred to as responsibility without error. Mistakes here are meant to be mistakes in a legal sense. It could be that the act is still morally wrong. However, there is also a lot of responsibility for acts, whether deliberate or negligent, that undermine the interests of others, interests which are protected by law is a responsibility without error legally or morally [7].

The principle of responsibility is a very important subject in consumer protection law. In cases of violation of consumer rights, caution is needed to analyze who should be responsible and how far the responsibility can be borne by the parties concerned.

In general, the principles of responsibility in law can be distinguished as follows:

1. error (liability based on fault)

2. presumption is always responsible (presumption of liability) 
3. presumption is always irresponsible (presumption of no liability)

4. absolute liability,

5. Limitation of Liability.

The responsibility of business actors to consumers according to Law number 8 of 1999 concerning Consumer Protection in article 19 states as follows:

(1) Business actors are responsible for providing compensation for damage, · pollution, and/or loss of consumers due to consumer goods and/or services produced or traded.

(2) Compensation, as referred to paragraph (1), can be in the form of refunds or replacement of goods and/or services of a similar or equivalent value, or health care and/or provision of compensation according to the provisions of the applicable legislation.

(3) The compensation is given within 7 (seven) days after the transaction date.

(4) The granting of compensation as referred to paragraph (1) and paragraph (2) does not eliminate the possibility of criminal prosecution based on further evidence regarding the existence of an element of error.

(5) The provisions referred to in paragraph (1) and paragraph (2) do not apply if the business actor can prove the error is the fault of the consumer. "

The provisions in article 19 paragraph (1) and paragraph (2) are unclear and do not provide adequate legal protection for consumers of aviation services, because compensation is determined in the form of choices, such as refunds or replacement of goods. This is unfair to consumers and is not according to the principles of consumer protection. As stated by Ahmadi Miru the principle of consumer protection is divided into the protection of the health/property of consumers as well as protection of goods and prices. [8]

This means that compensation to consumers is not only limited to the replacement of goods or refunds but the number of losses suffered by health due to consumer goods from business actors, all of which should be taken into account both material and immaterial losses.

Regarding the flight itself, the responsibility of the carrier is regulated in articles 165 through article 173 of Law No. 1 of 2009 concerning Aviation.

Article 165

(1) The amount of compensation for each passenger who dies is permanently disabled or injured as referred to in Article 141 paragraph (1) shall be determined by Ministerial Regulation.

(2) The amount of compensation as referred to in paragraph (1) is the amount of compensation provided by the commercial air transport business entity outside the compensation provided by the insurance agency determined by the Government. Article 166

Carrier and passenger can make a special agreement to determine the amount of compensation higher than the amount of compensation as referred to in Article 165 paragraph (1)

\section{Article 167}

The amount of compensation for cabin baggage as referred to in Article 143 shall be stipulated as high as the actual loss of passengers.

\section{Article 168}

(1) The amount of compensation for each checked baggage and cargo as referred to in Article 144 and Article 145 shall be determined by Ministerial Regulation.

(2) The amount of compensation for damage or loss of part or all of the checked baggage as referred to Article 144 or the cargo as referred to Article 145 is calculated based on the weight of the checked baggage or the lost, destroyed or damaged cargo.

(3) If damage or partial loss as referred to in paragraph (1) results in the entire baggage or entire cargo being unusable, the carrier shall be responsible for the entire weight of the baggage or unusable cargo.

The regulation of this form of responsibility is not able to provide optimal protection for consumers of aviation services, the regulation of article 166 is very inconsistent with the previous article, where the constitution provides opportunities for the transporter and the consumer to determine the amount of compensation, which this will be very detrimental to consumers, given the weak position of consumers in front of business actors very unlikely that the carrier will provide higher compensation beyond what has been stipulated in the legislation.

Likewise, article 168 paragraph 2 is very detrimental to the determination of the amount of compensation for the amount of lost luggage weight, because the amount of consumer loss can not only be assessed by baggage weight because the value of goods or brands of luggage from the consumer's value is much more expensive. After all, businesses must provide compensation for goods and costs should be incurred by consumers to get the goods, but ultimately lost in transportation.

Looking at the existing regulations in the law, consumers will experience difficulties in making claims against business actors, so the application of absolute responsibility theory is very important to protect consumers, because the burden of proof is not in the hands of consumers as is usually the case in civil cases, but it is the business actors who must prove that the product or service it trades is safe and does not endanger consumers. With the application of absolute responsibility, the business actor who manufactures the product or the equivalent is considered guilty for the loss suffered by the consumer, unless he can prove otherwise, that the loss incurred cannot be blamed on him [9].

\section{CONCLUSION}

Both the Consumer Protection Act and the Aviation Law (UUP) do not regulate the responsibilities of business operators for consumers of aviation services, there is a need for reconstruction of the UUP as a special provision governing the aviation sector about the safety, 
security, and responsibilities of parties carrier of aviation service consumers as passengers, so consumers get their rights if harmed, and more specifically aviation safety standards are optimal for maintaining consumer safety.

\section{ACKNOWLEDGMENT}

Thank you for Dean Faculty of Social Sciences for supporting this research.

\section{REFERENCES}

[1] Www.anasir.com, 'Negara dengan penduduk terbanyak didunia'. .

[2] www.indinesiafinancetoday.com, 'Optimism konsumen indonesia tertinggi'. .

[3] J. Sidabolok, Hukum Perlindungan Konsumen. Bandung: Citra Aditya Bakti, 2006.

[4] A. Ridwan Halim, 'Pengantar Ilmu Hukum
Dalam Tanya Jawab'. Graha Indonesia, Bogor, 2014.

[5] H. Kelsen, Pure Legal Theory; Basics of Normative Law as Descriptive-Empirical Law. Jakarta: JAKARTA RIMDI PERS, 1995.

[6] J. Asshiddiqie and A. Safa'at, Teori Hans Kelsen tentang Hukum. Jakarta: Konstitusi Press, 2006.

[7] F. Munir, 'Perbuatan Melawan Hukum'. PT Citra Aditya Bakti, Bandung, 2002.

[8] Ahmadi Miru, Prinsip-prinsip perlindungan hukum bagi konsumen di Indonesia. Surabaya: erlangga, 2006.

[9] A. Sutedi, Tanggung jawab produk dalam hukum perlindungan konsumen. Bogor: Ghalia Indonesia, 2008. 